Sergei V. Sokolowskiy

\title{
A BUNDLE OF DISPARATE INTERESTS: Research Fields and Sub-Disciplines in the Present-Day Russian Antbropology*
}

Names are often misleading, the names of the disciplines doubly so. What went by the name of anthropology in Russia just a few years ago (and is still going on beyond its capitals and large universities) often needs elaborate comments and long explanations for our colleagues elsewhere. In gross terms, the predominant occupations of Russian (socio-cultural) anthropologists cum ethnologists might be roughly grouped into two large and mutually independent (in terms of research activities, journals, reading audiences, and mutual citations, or, better, the lack of latter) domains. The first and more populated area is the study of the socalled nationalities policy with its perpetual issues, such as nation-building, inter-ethnic relations', 'ethnic conflicts', minorities' and indigenous peoples' rights, the policies of ethnic categorization and ethnic groups recognition, identity politics, multiculturalism and tolerance. The second, less directly influenced by political whims and fashions is the old Russian tradition of anthropological research that is centred on what is elsewhere known as ethnology proper, with its own conventional objects - folklore, mythology, traditions (or what is vaguely termed 'traditional culture'), customs and rituals, and with its recent interest in more fluid and flimsy urban ways and lifestyles. There are also physical or bio-anthropology and archaeology, but they are not viewed as parts of Russian anthropology: most former 'ethnographers-turned/cultural/anthropologists' consider these specializations as separate disciplines, albeit often sharing the same administrative and financial resources as 'anthropology proper' (on the rare exceptions, see below) ${ }^{1}$.

There is yet one more fairly large and mixed group of researchers, working at anthropological institutions and research centres across the country, who are by their training and current preoccupations could be more suitably described as historians, sociologists, philosophers, linguists, demographers, biologists, geographers, geneticists, etc. The subjectmatter of their research projects combined with vestiges of loyalty to the disciplines they have been trained in, on the one hand, and their research positions within anthropological departments, on the other, turn them into 'human bridges' that both facilitate interdisciplinary endeavours and fragment what has gone so far under the name of Russian anthropology into more and more specialized research fields. This third category is defined against the first two as not-specializing in their respective subject-matters, and thus do not constitute a separate and homogeneous area of research interests, but more a classification artefact, a diverse assembly of interdisciplinary research associated with anthropological centres.

As particular research projects operate in specific timeframes and locations, so most of the experts within the three categories listed above simultaneously practice some regional and (especially in the case of historians cum anthropologists) bistorical period specializations that criss-cross the divides among 'political anthropologists', 'folklorists' and 'inter-disciplinarists', occasionally bringing them together in joint research of a particular locus, regional (and less frequently - history) departments and regionally specialized publications.

Fragmentation and differentiation of research agendas and interests within each of the two main divisions of Russian anthropology had their own pace and chronology, that roughly coincided only in periods of societal crises or major political turmoil and/or administrative changes. The oldest specializations, among them folklore studies, the study of ethnic history

" Draft paper for article collection on European anthropologies (editor: Peter Skalnik), submitted on March $15,2017$. 
and ethnogenesis, physical and legal anthropology, and archaeology with special emphasis on ethnic groups origins, inherited from the XIX c., were reformed according to the dogmas of the Marxist social theory in the period of 1930-50s, which due to the needs of the war effort and post-war reconstruction (including new political borders demarcation) saw also the beginnings of two new subdisciplines within Soviet etnografia: ethnic demography and ethnic cartography.

The second wave of differentiation started during the late 1960s and continued through the 1970s to mid-1980s, when a number of hybrid sub-disciplines were institutionalized as research departments at the Institute of Ethnography, a part of the Academy of Sciences of the USSR (further IE $\mathrm{AN}^{2}$; now the Institute of Ethnology and Anthropology, IEA RAS), the main research institution that co-ordinated ethnographic research throughout the country and had a number of branches across it, including its Leningrad branch that now constitutes an autonomous anthropological research centre, the famous Kunstkamera. Among the new sub-disciplines were ethno-sociology, ethnic ecology, and ethnic psychology - specializations for which it would be hard to find analogues elsewhere, for they were based on a peculiar version of ethnic group conceptualization that came to be known as the Soviet theory of ethnos (for details, see: Banks 1996: 17-23; Bromley, Kozlov 1989; Chichlo 1984, 1985; Dragadze 1980, 1990, 1995; Gellner 1988; Skalnik 1986, 1988).

The third wave of fragmentation of the discipline's research subject occurred at the end of 1980s and beginning of 1990s, with institutionalization of such 'ethno-prefixed' subdisciplines as 'ethno-conflictology' (a sort of applied political anthropology with a focus on the study of 'ethnic conflicts'), ethno-gender studies (gender relations studied, again, within particular ethnic groups and at the intersection of ethnic and gender identities), as well as such less idiosyncratic disciplines as urban, visual, medical and economic anthropology.

Today, when Russian anthropologists start to turn their attention to research of science, technology, sport, tourism, state administration, business organizations, media, fashion, body, dreams, emotions etc., we witness the fourth wave of research domains differentiation, producing small anthropological communities, specializing in STS, media, or cognitive and sensorial anthropology.

It might be worth noting, that due to the over-centralized character of the Soviet academy, the emergence of new research domains and sub-disciplines roughly coincided with major administrative changes at the main centre of ethnographic research - the Institute of Ethnography, each new director of which came with his own ambitious theoretical innovations that dictated changes, sometimes quite radical, in research agenda of the whole discipline ${ }^{3}$. The other two most important factors that contributed to the development and change of research agendas and the growing scope of the discipline's subject were progressive 'etatisation' (with its pernicious 'governmentality') among anthropologists, specialising in nationalities policy research, expressed in proliferation of applied research either controlled by the state institutions or motivated by the state interests, on the one hand, and the quirks and whims of academic fashion, on the other, shifting their attention from visual to medical anthropology, or from gender research to STS.

In what follows, I shall try to outline the specifics of some of the recently emerged research domains and sub-disciplines within that broad field of social and cultural research in Russia, that is practiced by those who call themselves anthropologists or ethnologists, and who are either employees at various anthropological institutions and university centres, or freelancers. The main sources for this undertaking are insider information ${ }^{4}$, and the recently formed, but powerful academic information database e-library.ru (comprising now over 25 million publications by 800 thousand authors, among them 10 thousand historians and 4.5 thousand sociologists - degrees that Russian anthropologists get after successful $\mathrm{PhD}$ defence), as well as anthropological websites in ru.net. 
I have already noted above that the leading specializations in Russian anthropological research, the two large loosely grouped autonomous domains, are not easily mapped onto disciplinary divisions and boundaries in other national traditions. Russian "political anthropology" in terms of its current research foci tends to transgress standard understanding of this field and could be more correctly labelled as applied research in nationalities policy, often done in close co-operation with federal and regional authorities. The second domain, "ethnographic folklore studies", admittedly closer to traditional anthropology's concerns, are of special interest for our colleagues in Western universities, but not so much for anthropologists, as for Slavists and, sometimes, for scholars in cultural studies. This mismatch between what is commonly understood as legitimate anthropological concerns in the rest of the world (former Soviet block countries are notable exceptions), on the one hand, and the research interests of Russian 'ethnographers-turned-anthropologists', on the other, creates the inimitable and eclectic character of the Russian discipline and produces confusion in our contacts with colleagues from abroad. As a result anthropologists from Russia are more often and in greater numbers seen at ASN, CESS, or ASEEES, that is, with political scientists, regional specialists, Slavists etc., than at anthropological congresses such as AAA or EASA.

\section{POLITICAL ANTHROPOLOGY A LA RUSSE}

Russian brand of political anthropology, more known as etnopolitologia, continues from its inception in early 1990s to suffer from, according to an apt phrase by one of its leaders, "a lack of discipline" (Tïbkov 1994: 91). A motley combination of disparate methods drawn ad boc from a number of neighbouring disciplines, such as political sociology, human geography, social demography, conflict studies, history of nationalities, empire studies, etc., and propelled mainly by the vicissitudes of political fashion and ever-changing federal and regional political elites interests, it has never reached either a coherent methodology, or even a definable and conclusive set of research objects. Drifting from one applied project to another, changing regional emphasis from Chechnya to Tatarstan, and from South Ossetia to Crimea, and its topical focus from ethnic conflicts to ethnic group voting behaviour, or from population census to education reform, its practitioners have never considered a coherent agenda or theoretical consistency. The area's boundaries in sociological terms are defined more by the vagaries of government research tenders and the state apparatus of social science knowledge, than by its own dynamics, which is expected to progress due to methodological refinement or theoretical debates.

Admittedly, there were theoretical debates between the so-called 'primordialists' and 'constructivists', or rather adherents to Bromley's and Gumilev's versions of ethnos theory vs. 'western-oriented' proponents of ethnicity in 1980s and 1990s, but these discussions subsided by the end of 2000s with inconclusive results (although rumour was, that 'constructivists' took the upper hand). The results of the attempt to organize a similar discussion on the concepts of nation and nationalism with its evident political application to the case of the Russian nation (Tisbkov 1998, Tisbkov of Shnirelman 2007, Tisbkov os Filippova 2016) are yet to be seen. Systems-theory and/or information-theory approaches that were in vogue during the nascent days of Soviet ethnos theory (cf.: Arutionov 1989: 19-41, Pimenov 1977) and that might had suited theoretical needs of the whole enterprise (cf.: Avksentiev 1996) were dropped, together with the concept of ethnos, except in tangential cases of ethnic conflicts conceptualization.

The tangled roots of etnopolitologia, disguising prevalent political myths under social sciences jargon, brought a plethora of publications, the subject of which remains elusive: e.g. in a paper with a simple enough heading "Ethnic Conflict in N-sk", published in one of a score of Russian anthropological journals, one might find either a sketch of an ethnic 
composition of urban population with a focus on migrants, or an analysis of identity dynamics of a certain social group, or an outline of electoral behaviour of its citizens, or a subculture study, or report on a strife over regional budget, or a combination of several topics just listed.

Soviet version of political anthropology, although called differently (notably, etnopotestarnaia etnografia, from Latin potestas - power) suited the label of anthropological subdiscipline much better than its current successor etnopolitologia, but as often happens with sweeping generalizations of such vast fields as etnopolitologia in Russia ${ }^{5}$, there are noteworthy exceptions that one might appropriately define as 'political anthropology proper'. Among them, the work in quantitative history of state-building in pre-industrial societies by Nikolay Kradin and Andrey Korotayev, on the history of political anthropology by Viktor Bocharov, and Africanists studies by Vladimir Popov and Dmitry Bondarenko (with such eminent predecessors as Dmitry Olderogge, Lev Kubbel, Abram Pershitz, or lesser known among ethnographers Olga Tomanovskaia and Yulia Zotova). Much of such research could be perceived as classic social anthropology with its traditional attention to kinship terminology, social structure and cross-cultural comparisons. But they remain a tiny portion of the voluminous etnopolitologia's print production. Most of the courses read at various anthropology departments across the country include much more often readings on the mundane objects of etnopolitologia, including ethnos and ethnicity theories, ethnic conflicts, but rarely a course on political anthropology proper.

The already mentioned endemic to this field 'lack of discipline' has its roots in the current administrative arrangement of the Russian academy and of its research funding. With what came to be perceived as the 'threat of colour revolutions', Western research grant agencies were made to leave the country or to drop their most effective research grant programs ${ }^{6}$. Academic research became again almost exclusively government or statesponsored, as it was in USSR. The difference is that back in Soviet planned economy times an individual scholar got her research support from her own institution, now when research is supported by grant agencies, much depends upon their policies and procedures. Most of the Russian anthropological research institutions do not have any special fundraising units, and researchers have to procure grants themselves, but this is a minor although time-consuming problem. The real problem is the pozoonochnoe pravo ('telephone call law'), reigning at the Russian granting agencies, whose councils are not elected, but appointed by academicians and research institute directors (often the same persons), whose protégés (staff members of the same institutes) during the selection procedures (far from anonymous, as nobody tries to conceal the applicant's name) closely follow the 'advices' given by their seniors. The result is that from one year to the next the lists of the winners have the same names (bosses included) with slight variations of research topics, getting more stale and sterile with every year passing. The standards of double-blind peer-review or transparent procedures of expert board formation have never taken root in all of the major state-sponsored research granting agencies; bureaucracy is fond of controlling finance and proficient in channelling it in 'appropriate' directions.

\section{ETHNO-PREFIXED SUBDISCIPLINES}

The focus on applied research in nationalities policy, that formed the core of Soviet ethnographic studies during the post-war period, gave birth to a plethora of 'ethno-prefixed' sub-disciplines and contributed both to modernisation of Russian etnografia, and multiple alliances with neighbouring social sciences and humanities. Among the offspring of such alliances were ethno-demography, ethnic geography (ethnic boundaries and migrations mapping), ethno-statistics (categorization of population and its applications to population census programmes). At a later stage these pragmatically driven set of sub-disciplines were 
supplemented by several more academically oriented research specialisations, such as ethnic ecology, ethnic sociology, and ethnic psychology, all of which were believed to be specialized bodies of knowledge that could contribute to a better understanding of ethnic processes and through light on the most fundamental theoretical unit of Soviet etnografia-etnos.

\section{Etbno-Sociology}

Another close kin of etnopolitologia was the so-called etbno-sociology, the child of Yulian Bromley's attempt at the end of 1960s at Russian etnografia modernization, when he invited Yurik Arutyunian and Ovsey Shkaratan, two sociologists from Leningrad, to open new sociological department at IE AN. Today when the heyday of this discipline is over, and there are no large-scale ethno-sociological 'expeditions', typical for the period of 1966-1986 (see for sub-discipline's history and a list of collective fieldwork ventures: Komarova 2016: 306-311; Drobizheva 2001), the initially productive alliance between etnologia and sociology in this particular area of ethnic groups sociology dried up to a trickle of publications, devoted for the most part to documenting its history, rather than to the results of contemporary research, which shifted to ethno-political concerns (the study of nationalist activism, ethnic elites research, etc.), which could be better asssessed as a part of political sociology rather than anthropology.

\section{Ethnic Conflicts Research}

Yet one more off-shoot of ethno-political and ethno-sociological research with a brand name of etnokonfliktologia (ethnic conflicts research) had been initiated in early 1990s by a small group of ethnologists and sociologists, situated mainly at the two academic institutes (IEA RAN, and the Institute of Sociology RAN) in Moscow. With proliferation of violent conflicts and separatist movements in late 1980s and early 1990s it quickly spread into various research centres across the country. Back in Soviet times there were no conflict studies, except family conflict studies by social psychologists and psychotherapists, hence Russian ethnologists and anthropologists had to devise conceptual schemes and theories from scratch or to borrow them from other research traditions, combining vocabularies of demography, geography, social psychology, sociology, political sciences, and history. The results were, in terms of academic research, often discouraging, but their activities as knowledge brokers and raw data providers paid well. On more positive side, the 'ethnic' conflicts ${ }^{7}$ research brought better familiarity with political theory, including current theories of federalism, of separatist movements and conflict dynamics, migration research, conflict monitoring and early warning systems, etc. However, if one asks what makes one think that these preoccupations still might be perceived as anthropology (or for that matter ethnology), one would be forced to admit that they are mainly institutional (this type of research proliferate at anthropological research centres) and administrative factors, among them a long tradition of government use of academic research with corresponding demand, only reinforced by the state funding, for the research to be applied. Both methodology, and prevailing theoretical approach of this subdiscipline belong to political sciences and sociology of ethnic relations, and although most of the scholars from this community work at anthropological institutes and centres, their university specialties vary widely, and the community predominantly includes former geographers, sociologists, demographers, psychologists, historians, linguists, but very rarely those, who had been trained as ethnologists or anthropologists. Hence, the prevalent research methods are surveys, formal interviewing, discourse analysis and archival research; field research and participant observation remaining a rare exclusion. 


\section{Ethno-Psychology}

The attempts to found ethnic psychology roughly coincided with the establishment of ethno-sociological departments in late 1970s and early 1980s, but with comparably fewer numbers of psychologists in the country, they were never on a par with ethno-sociologists and often joined them in on-going research projects. The first attempts to find the constituent subject that would anchor the sub-disciple as a separate field were awkward. The old romantic idea with strong Herderian flavour that every 'ethnos' should have distinct 'psychological make-up' dangerously bordered with racialism, if not subtle academic ethnoracism. Subsequent readjustments and corrections of research focus as the study of ethnic stereotyping and intolerance in 1990s and re-naming of etbnopsikbologia in line with similar research traditions elsewhere into cross-cultural psychology in 2000s slightly corrected the drawbacks of its false start, but this happened at the time when preoccupation with etnos as the main object of etnologia were past, and most of 'ethno-prefixed' sub-discipline communities declined in numbers or 'migrated' from anthropological research centres either to university departments of its kin disciplines (e.g. to political sciences and psychology departments in cases of etnopolitologia and ethnopsikhologia, respectively), or to the main institutes of the Russian Academy of Sciences (as in the case of ethno-sociologists some of whom left IEA ). The preoccupation with everything ethnic in its early formative period has not been entirely overcome till the present day, with the result that the re-christened sub-discipline never fitted its 'cross-cultural' prefix, as it continues to focus rather on 'cross-ethnic' comparison. The ethnic culture assumptions remain so deeply entrenched, that the rich heritage of multiple inter-dependencies between culture and psychology, exemplified in the works by Lev among the Vygodskiy and Aleksandr Luria, have never found its expression in the works of ethnopsikhologia practitioners.

\section{Ethno-Ecology}

Ethnic ecology (etnoecologia) emerged as a distinct sub-discipline in early 1980s and is taught now mostly at geography departments at a university level. It coalesced from several research strands during 1970s, although much of its research of, for example, subsistence types, predated the institutionalisation of this specialisation by several decades. Among its various precursors were Waldemar Bogoraz, who had suggested detailed typology of culture, including its subsistence components, which he categorized in his famous "Chukchee" in large groupings of 'habitat' and 'habitation' (1904: 12-16; 169-183); Sergey Tolstov, who provided a list of subsistence types of pre-historic societies in his "Essays on Early Islam" (1932: 31-32); and Maxim Levin, who analysed the historical succession of subsistence types among peoples of the Russian Arctic (1947).

The concept of the so-called economic-cultural types (kulturno-kboziaistvennyi tip), to a large degree influenced by the J. Steward's ideas of cultural ecology (1955), was elaborated by Boris Andrianov and Nikolay Cheboksarov (1972). Later, these typological insights were developed by Lev Gumilev $(1967,1971)$ and especially by Valery Alekseev $(1975,1984)$, who suggested the closely related concepts of anthropocenosio and anthropogeocenosis, respectively.

Other theoretical strands that contributed to the development of applied human ecology were studies of human groups adaptation to various climatic and geochemical conditions, both anthropological (Tatyana Alekseeva and her colleagues at the Moscow Institute for Anthropology, a bio-anthropological research centre of the Moscow State University), and medical (pursued mainly at the Institute of Clinical and Experimental Medicine, Novosibirsk).

Yet one more important concept of subsistence system (systema zhizneobespechenia) formed a distinct research focus within human and cultural ecology (Sergey Arutiunov and 
his colleagues) and applied cosmic biomedicine (Vlail Kaznacheev, Siberian Dept. of the Academy of Medical Sciences of the USSR).

The ethnographic sub-discipline got its present name in 1981, when Viktor Kozlov, Soviet ethno-demographer and ethno-geographer, headed ethnic ecology department at IE AN, that was an outgrowth of a joint Soviet-American project for the study of human aging and longevity, initiated in $1977^{\circ}$. Ecology at the time was a highly fashionable discipline, exerting its influence on social sciences and humanities ${ }^{9}$, and Yulian Bromley, who was a full member of the Academy of Sciences, wanted that the institute he directed was on the cutting edge of contemporary research in human and social sciences. Although the department at IEA RAN still exists, very few scholars now practice ethnic ecology proper.

\section{Ethno-Gender Studied}

The latest among 'ethno-prefixed' sub-disciplines, 'ethno-gender studies' (etnogendernye isoledovania), was institutionalized at IEA RAN as a research group in 1992 (in 1997 this group received the status of a sector). Russian sociologists and sexologist Igor Kohn acted as its informal leader in its starting years. The group under his leadership initiated gender studies in Russia, covering the broad range of feminist theory, masculinity, LGBT issues, family studies, etc. The prefix 'ethno-' served as a sort of cover, explaining why the group was a part of IEA RAN. In 2006, Natalia Pushkareva, a specialist in medieval history, headed the sector and changed its research priorities by channeling them into women's history.

There are several other gender research centers in Russia with inter-disciplinary agenda, but their members do not usually associate themselves with ethnology and do not need to style their discipline as having to do with anything 'ethnic'; neither do they specialize in history, as it was characteristic of Soviet etnografia (ethnology) that was considered a historical discipline.

Most of 'ethno-prefixed' disciplines, the heritage of 1980s, moored to the concept of ethnos, are now either marginalised and survive in academic periphery, or slowly dissolve along with primordialist views on ethnic phenomena and attempts at positivist theorybuilding.

\section{FOLKLORE STUDIES AND ‘ADJECTIVAL’ ANTHROPOLOGIES}

\section{Folklore studies}

There is a view that folklore studies constitute the core of Russian etnografia and should be considered as ethnology proper, compared to other more recent off-shoots and 'deviations' of anthropological research. Historically and even sociologically (in terms of the number of people involved and overall number publications) this is true, as most museum anthropologists remain faithful to this tradition. There are two main sub-divisions within mainstream folklore studies in Russia, roughly, folklore studies made by linguists with the general task to map dialectal boundaries (e.g., Centre for Typology and Semiotics of Folklore of the Russian State University for Humanities in Moscow; State Centre for Russian Folklore of the Ministry of Culture in Moscow; Ethno-linguistics and Folklore Department of the Institute for Slavic Studies, RAN, etc.), to analyse dialectal linguistic stocks, morphology, grammar, etc., on the one side, and ethnographic or anthropological folklore studies with a focus on ritual, customs, material culture, contemporary urban folklore (e.g., Anthropology Department at the European University in St. Petersburg; Russian Studies Department at IEA RAN), on the other. Both sub-divisions have their own traditions in the long histories of linguistic and ethnographic research, respectively, and though sometimes overlap, remain distinct not only in perspectives and methods, but also sociologically, in terms of research 
networks and publications. 'Linguistic' folklorists tend to communicate more with linguistic anthropologists and dialectologists, whereas 'ethnographic' folklorists often practice urban anthropology or are involved in religion studies. The first publish their research in such journals as Traditional Culture, Antiquities Alive, or Slavic Studies, whereas the second tend to send them either to Forum for Antbropology or Ethnographic Review (see for details: Table 2 in the Attachment). Folklore studies in this sense embrace much of urban and linguistic anthropology, and anthropology of religion, as well as parts of visual and medical anthropology.

\section{Urban ethnography}

The broad research area of urban studies, sometimes designated as urbanistika, constitutes a separate domain of multidisciplinary research, where urban planners, architects, geographers, historians, sociologists, archaeologists and anthropologists interact. In anthropology (or to use the original term of the period, when urban studies emerged as anthropological concern, etnografia), the study of urban population started back in the early 1950s with the demand to focus on contemporaneity and contemporary culture (versus previous exclusive focus on tradition). The initial research focus was the culture and folklore of the urban working class. Peasant ethnography was to be supplemented by proletariat studies to embrace the whole 'people', the main subject of etnografia; other urban strata remained a peculiar blind spot for much of the Soviet period. Etnografia has established itself in Soviet academy from mid-1930s as a historical discipline, so the study of contemporary mores and ways looked at the time as a major innovation. As it often happens with innovations, the conceptual means and models were lacking, so the standard methods of rural peasant studies were extended for application to the new research objects. Predictably the predominantly descriptive studies of the 'working class culture' had not brought any conceptual advance, but it made the focus on urban population strata in Soviet ethnographic research to seem an appropriate ethnographical enterprise and introduced comparatively modern-day traditions as legitimate objects for anthropological analysis.

New research methods, including mass surveys and focus groups research came to sub-discipline with the rise of ethno-sociology in 1980s. A new focus of research emerged in 2000 s, when urban youth sub-cultures attracted attention of the young generation of Russian anthropologists, who were influenced by success of Birmingham youth culture studies. Subculture concept critique that followed brought a substantial decrease in the number of such studies. Table 1 in the Attachment summarises the topical changes in urban ethnographic research by 10-years periods as reflected in publications of the Russian anthropological journal "Etnograficheskoe obozrenie"10.

\section{Antbropology of religion}

This is an old, vast and thriving research domain in Russian anthropology, converging with religion studies (religiovedenie), that often overlaps with regional specializations (e.g. most anthropologists, specializing in Caucasus, Volga or Central Asian studies contribute to the study of Islam; many 'Siberianists' pursue research of shamanism, folklorists often excel in the knowledge of Orthodox rites, etc.). The discipline is not institutionalized in current Russian anthropology, except for regular publications and occasional university courses, but as the study of rituals and customs continues to be the backbone of much field ethnography, anthropology of religion remains a subject that many Russian anthropologists could claim as their own. 


\section{Linguistic antbropology}

There are very few Russian anthropologists who could claim to pursue linguistic anthropology, and most of these few are linguists by training. It so happened, and linguistic diversity of the country's population might be an explanatory factor here, that few anthropologists learn the language of the group they (initially) study, and in most cases when they know it, they know it either from childhood by being a so-called 'native' anthropologist, or by being a long-time resident of the region. Many regions of the country are multi-lingual, as its linguistic diversity (about 200 languages) outstrips the number of languages in any European country by degree. This creates an unusual background for the career choices of a young anthropologist: you can invest your time in learning the language and get stuck for much of your career with one (often quite small) group, or you specialize regionally by thorough acquaintance with history, geography, culture, archives etc. of a whole region that holds many diverse groups, traditional residents of the region, but you converse with them in Russian ${ }^{11}$, perhaps with a few occasional phrases in their own languages. Hence most anthropology departments in the country do not demand from their students the knowledge of local languages (knowledge of English is considered more important as much of the literature is in it), and the few post-doc departments that do, have narrow regional focus.

Linguistic field anthropology in Russia remains rather a linguistic than anthropological discipline with a focus on socio-linguistic research and with academic research centres, situated either at linguistic university departments (Novosibirsk, Tomsk and Chita universities), or at the institutes of Russian Academy, such as the Institute of Linguistics RAN in Moscow and the Institute of Linguistic Studies RAN in St. Petersburg; European University in St. Petersburg. In 1960s-1980s there was a group for the study of onomastics (the study of proper names, including ethnonyms and toponymy) at IE AN, related to ethnogenesis and ethnic migrations research, but with the decline of ethno-genetic studies, the group ceased to exist.

\section{Visual anthropology}

Although Soviet visual anthropology is often linked with Dziga Vertov and his documentary film theory of 1920s, most Russian visual anthropologists (aside from field photography and occasional shooting of rituals that had been considered as a mere instrumental 'fixation' of field materials, along with pencil drawings, diary writing, and audio recording) date their discipline's birth as summer 1987, when the first Soviet ethnographic film festival was held in Pärnu, Estonia (cf. Aleksandrov 2007: 9). It took about next ten years for Russian visual anthropology to mature, before the first Russian anthropological film festival took place in Salekhard in August 1998 ${ }^{12}$. In 2002 Moscow International Visual Anthropology Festival was organized to become a bi-annual event. Now, besides the Centre for Visual Anthropology at MGU, there are groups of enthusiastic visual anthropologists at Saratov Technological University, as well as in Izhevsk (Udmurt Republic), Perm, Yekaterinburg, Novosibirsk, and St. Petersburg.

\section{Legal antbropology}

The study of customs and customary law were inalienable parts of ethnological research in Russia since its formation in XVIII c. (for details, see: Vermeulen 2015). However, it was constituted as a distinct anthropological discipline only in mid-1990s, when anthropologists and jurists joined their efforts to establish juridicheskaia antropologia as a set of teaching courses, summer schools, conferences and a series of publications, mainly in the form of conference reports (cf.: Benda-Beckmann, Finkler 1999), article and documentary collections and occasional monographs, focussing mainly on indigenous peoples or minority groups rights or the study of Shari'a law and adats as forms of customary law. Russian anthropologists, 
specializing in these subjects, often act as consultants or experts in legislation process in cases that concern nationalities policy issues or at courts that deal with violations of indigenous and minority rights or with the cases of xenophobia and intolerance.

\section{Medical anthropology}

The discipline bearing this name has been for a long time considered a part of medical students curriculum, while Soviet ethnographers paid only occasional attention to the socalled traditional medicine and healing practices. This situation started to change in 1980s in the context of multi-disciplinary aging and longevity studies (see section on ethnic ecology above), when ethnographers and physical anthropologists worked in close collaboration with geriatricians. During that period many of the standard issues and research topics a medical anthropologist usually grapple with, were studied in social hygiene, medical geography and the history of medicine. As a part of socio-cultural anthropology the discipline started its institutionalisation only in 2000s, when Valentina Kharitonova at IEA RAN initiated regular seminars and conferences, initially concentrating on traditional healing and shamanism research. Now medical anthropology is being taught and practiced at several university centres (besides Moscow, also in Saratov and Tomsk), but it remains quantitatively a relatively small community, if one compares it with USA, encompassing perhaps only several dozens of Russian anthropologists, who promote it and are actively involved in medical anthropological research projects.

\section{Economic anthropology}

One might credibly assert that economic anthropology does not exist as a separate discipline in Russian anthropology or, at best, it goes through its nascent period of institutionalization, although there are university courses and textbooks bearing the title. This is a paradox, as world-renowned economic anthropologists, such as Alexander Chayanov, lived and worked in Russia. It is a double paradox, as presumably Marxist Soviet etnografia should have paid much more attention to 'economic base', production, exchange, and consumption research than it was the case. However, to state that there is no separate discipline under the name of "economic anthropology" in contemporary Russian academy is not equivalent to the statement that there is no anthropological research on economical issues. In fact the research of many issues that could be referred as 'economic' have been practiced by Soviet ethnographers throughout Soviet period, although such research was often dispersed in terms of intra-disciplinary arrangement of academic labour division. For example, the typology of the economic-cultural types (see the section on ethnic ecology above) demanded close knowledge of the economy of societies classified. Material culture studies contained much information on traditional economies of the societies studied. There was an animated discussion of economic formations and of the Marxist concept of Asiatic mode of production; the modes of production were part of the research agenda of the department of pre-historic societies (sector pervobytnoi istorii) that had been created at IE AN in 1967. Theoretical contributions to pre-industrial economies research, made by the staff members of that department (Abram Pershits, Yuri Semyonov, Lev Kubbel, Vladimir Kabo, Viktor Shnirelman, Olga Artemova), as well as a series of translations into Russian of the works that became classical in economic anthropology (Henry Morgan, Marcel Mauss, Bronislaw Malinowski, Maurice Godelier and Marshall Sahlins, among others) attest to the rich tradition of economic-anthropological research in the country. Attempts to the institutionalisation of the discipline continue (e.g. there was a baccalaureate course at the Higher School of Economics, Moscow branch in 2012-2014, read by Nikolai Ssorin-Chaikov and Grigorii Yudin). 


\section{NEW RESEARCH DOMAINS AND INNOVATIVE FIELDS}

\section{Anthropology of profesdions and leisure}

There were occasional publications (notably, in urban anthropology, when a certain subculture became a focus of research, but also in folklore studies, when ethnographer concentrated on folklore of, say, village smiths or herdsmen) that could be viewed as precursors to the anthropology of professions. However, the rise of this sub-discipline is usually traced to the works of sociologists, based at the chair for social anthropology and social work of Saratov Technological University and at the Centre for Social Policy and Social Research (Saratov), who conducted a score of thematic conferences and summer schools, and published a series of article collections on anthropology of various professions, occupations, and trades that contained a plethora of case studies, covering fieldwork among taxi-drivers and policemen, ballet dances and iron founders, cemetery workers and dentists, lawyers and healers (Romanov, Iarskaia-Smirnova 2005; 2007; 2011; 2012).

There is an emergent research field of anthropology of the state with small number of researchers, involving both anthropologists and historians that could be provisionally viewed as 'kin' to anthropology of organizations and institutions. The field is loosely institutionalized as a network of researchers, operating from Social Sciences and Humanities School of the Higher School of Economics in St. Petersburg and Anthropological Department of the European University in St. Petersburg (cf.: Abashin 2015; Ssorin-Chaikov 2003). Additionally, a Commission for Economic Anthropology has been recently created at the Russian Anthropological and Ethnological Association to encourage the development of this field. This approach is complemented by already mentioned comparative research in quantitative history of the state-building in pre-industrial societies, relying mostly on archival sources interpretation and cross-tabulation of ethnographic traits analysis in the style of G. Murdock.

There is no neat division of labour among anthropologists who specialize in such fields as anthropology of business and organisations, science and technology, medicine, transport, youth sub-cultures, or tourism with those, who are involved in research on anthropology of professions and leisure. Not only all these fields of interest significantly overlap, there is a substantial commonality in methods and theories employed, as well as mingling and mixing of approaches and vocabularies used. Predictably, these new research fields involve younger scholars, and all the centres that pursue this kind of research are not the research institutes of the Academy of Sciences or old anthropological departments, but relatively new university centres (the already mentioned Saratov, European University in St. Petersburg, Tomsk University, and the Higher School of Economics with its branches in Moscow and St. Petersburg). The students are often trained as sociologists, coming to anthropology for their degree or postdoc specialisation.

\section{Antbropology of science and technology}

This is a new research area in Russia (with diverse strands and a motley set of scholars) that has not yet gained the status of an anthropological sub-discipline or any institutionalisation beyond occasional university course or article collection. There are notable exceptions in terms of sustainable research networks that coalesced around such topics as the anthropology of the academy (Komarova 2008, 2010, 2013), or STS and ANT in anthropological research (Sokolovskiy 2015, 2016). However, most of publications in this area discuss the history of various sciences and disciplines, scholars' biographies, or institutional histories, as well as the history of particular ideas or technologies, or philosophical issues that might be relevant to the discussion of scientific theories, methods and their implementation. There is a special institute among academic institutions in Russian Academy of Sciences, that 
conduct and co-ordinate research in the field of history of science and technology and publishes several journals and serial article collections ${ }^{13}$.

\section{Sensory anthropology, body and movement studies}

This is an emerging new area for anthropological research in Russia, drawing anthropologists' attention to other channels of perception besides visual, and to kinaesthetics (previously, only dance studies were among the traditional objects of ethnographer's attention). Now, there appeared a number of publications on the anthropology of smell, taste, and touch (cf.: Pirogovskaya 2015; Vainstein 2003).

\section{Conclusion}

A very substantial part of what is going on under the umbrella terms of etnologia or antropologia in Russia is in fact applied political and sociological research, a highly ideologized government-sponsored sphere of dealing with issues of legislation consultancy, nationalities policy, 'ethnic situation' monitoring and so-called 'ethnic conflicts' (or alleged 'threats' of such conflicts), accompanied and supported by specific political discourse. In a way, albeit indirect, all these preoccupations reflect the current situation in the country, when various informal networks, including territorial local clans, ethnic groups, university 'brotherhoods', or plain criminal gangs infiltrate much of economy, politics and even academy (with aforementioned rule of 'telephone right') and compete and conflict over scarce resources, be it an administrative post, an economic advantage, or a research grant.

There is, however, another faction, or rather a set of various collectives and networks within Russian anthropological community, who specialise in what I termed here adjectival anthropologies' and 'new research domains', which much better suit the name of anthropology and are better integrated in current discipline's agenda especially when looked at from an international perspective.

The two communities, although often sharing the same administrative resources, rarely collaborate. They rely on different research methods; they have different explanatory frameworks in terms of their theoretical sympathies, conceptual glossaries, or peer and authority structures. They also publish their papers in different periodicals and do not cite each other's work. Nowadays anthropology of almost any national tradition is fragmented into many sub-disciplines and specialised research fields. This is also the case of Russian anthropology, but unlike the situation in many other traditions, Russian anthropological community is also split into two 'camps', not necessarily warring with each other, but definitely looking to different directions and projecting quite distinctive 'futures' of the discipline. The research agenda of political anthropologists in Russia is closely bound with the current tasks of the nation state and might be viewed as a version of academic or methodological nationalism. I have argued elsewhere (Sokolovskiy 2014) that the second largest group, the folklorists, involved in 'traditional culture' research, are prone to another version of nationalism that might be viewed as academic historicism, as their findings are often used by all sorts of local nationalists to boost their claims either to the status of first inhabitants of some region, or to some kind of ancient and noble roots that put their communities well above the rest. Both strands of academic research produce research of somewhat parochial variety, although there is a number of emerging anthropological research fields, that are quite new for Russian anthropological tradition and that are capable to significantly transform its research agenda. 


\section{Bibliography}

Abasbin S.N. Sovetskii kishlak. Moscow: NLO, 2015. 720 pp. [Soviet kishlak].

Aleksandrov 2007 Vmesto retsenzii. V poiskakh predmeta vizualnoi antropologii // Antropologicheskii Forum. 2007. No. 7. P. 9-20 [In Lieu of Review: In Search of the Subject of Visual Anthropology].

Arutiunov S.A. Narody i kul'tury: razvitie i vzaimodeistvie. Moscow: Nauka, 1989. 246 pp. [Peoples and Cultures: Their Development and Interaction].

Avksentiev V.A. Etnicheskii konflikt kak vid sotsialnogo konflikta // Sotsialnyi konflikt. 1996. No.4. P. 33-51 [Ethnic Conflict as a Type of Social Conflict].

Banks M. Ethnicity: Anthropological Constructions. London: Routledge, 1996.

Benda-Beckmann K., Finkler H.W. (eds). Papers of the $\mathrm{XI}^{\text {th }}$ International Congress "Folk Law and Legal Pluralism: Societies in Transformation" (Moscow, August 18-22, 1997). Commission on Folk Law and Legal Pluralism, 1999. 395 pp.

Bogoraz W. The Chukchee. Pt. I. Material Culture. New York: G.E Steichert \& Co., 1904. (Memoirs of the American Museum of Natural History, Vol. XI).

Bromley J., Kozlov V. The Theory of Ethnos and Ethnic Processes in Soviet Social Sciences // Comparative Studies in Society and History. 1989. Vol. 31, no. 3. P. 425-438.

Chichlo B. L'ethnographie soviétique est-elle une anthropologie? // Rupp-Eisenreich B. (ed.) Histoire de l'anthropologie, $\mathrm{XVI}^{\mathrm{e}}$ - XIX ${ }^{\mathrm{e}}$ siècles. Paris: Klincksiek, 1984.

Chicblo B. Trente années d'anthropologie (etnografïa) soviétique // Revue des Etudes slaves. 1985. Vol. 57, No. 2. P. 309-324.

Gumilev L.N. Ob antropogennom faktore landshaftoobrazovania // Vestnik Leningradskogo universiteta. 1967. Vol. 24, no.4. P. 102-112 [On the Anthropogenic Factor of Landscape Formation].

Gumilev L.N. Etnos - sostoyanie i process // Vestnik Leningradskogo universiteta. 1971. Vol.12, no. 2. P. 86-95 [Ethnos: a state and a process].

Dragadze T. Politics and Anthropology in Russia // Anthropology Today. 1995. Vol. 11, No. 4;

Dragadze T. Some Changes in Perspectives on Ethnicity Theory in the 1980s: A Brief Sketch //

Cahiers du Monde russe et soviétique. 1990. Vol. 31. P. 205-212.

Dragadze T. The place of ethnos theory in Soviet anthropology // Gellner E. (ed.) Soviet and Western Anthropology. London: Duckworth, 1980.

Dragadze T. Soviet Ethnos Theory // RAIN. 1980. No. 38 (Jun.). P. 3-4.

Drobizheva L. Interview taken by Gennadii Batygin. Sept. 2001 (http://www.nir.ru/socio/scipubl/sj/sj4-01drob.html).

Gellner E. State and Society in Soviet Thought. Oxford: Blackwell, 1988.

Khazanov A.M. The Ethnic Situation in the Soviet Union as Reflected in Soviet Anthropology // Cahiers du Monde russe et soviétique. 1990. Vol. 31. P. 213-222.

Komarova G.A. Otechestvennaia etnografia i etnosotsiologia: opyt mezhdisciplinarnoř integratsii // Fenomen identichnosti v sovremennom gumanitarnom znanii. Moscow : Nauka, 2011. P. 273-297 [Russian Ethnography and Ethno-Sociology: The Practice of Inter-Disciplinary Integration. In: Identity Phenomenon in Contemporary Humanitarian Knowledge].

Komarova G.A. (ed.) Antropologia akademicheskoŭ zhizni. Tom 1. Moscow, 2008. 300 pp.; Tom 2. 2010. 331 pp.; Tom 3. 2013. 376 pp.; [The Anthropology of Academic Life, vols. 1-3].

Levin M.G. K problem istoricheskogo sootnoshenia khoziastvenno-kulturnykh tipov Severnoi Azii // Kratkie soobschenia Instituta etnografii AN SSSR. Moscow, 1947. Vol. 2. P. 84-86 [On the Problem of Historical Relationship of Economic-Cultural Types in Northern Asia]. 
Mirskii G. On ruins of empire: ethnicity and nationalism in the former Soviet Union.

Westport, Conn.: Greenwood Press, 1997. 185 p.

Motyl A., ed. Thinking Theoretically about Soviet Nationalities: History and Comparison in the Study of the USSR. - N. Y.: Columbia University Press, 1992.

Olcott M. Soviet Nationality Studies between Past and Future // Orlovsky D. (ed.) Beyond Soviet Studies. Washington, D.C., 1995. P.135-148.

Pimenov V.V. Udmurty: opyt komponentnogo analiza etnosa. Leningrad: Nauka, 1977. 262 pp. [The Udmurt: An Essay on the Component Theory of Ethnos].

Pirogovskaya $M$. Smells as miasma, symptoms, and evidence: on the problem of everyday life becoming scientized in late nineteenth-century Russia // New Literary Review. 2015. Vol.135, no. 5(http://www.nlobooks.ru/node/6546\#sthash.G2sT55bN.dpuf).

Plotkin V. Dual Models, Totalizing Ideology and Soviet Ethnography // Cahiers du Monde russe et soviétique. 1990. Vol. 31. P. 235-242.

Plotkin V., Howe J. The unknown tradition: continuity and innovation in Soviet ethnography // Dialectical anthropology. 1985. Vol. 9, No. 1-4. P. 257-312.

Romanov P.V., Iarskaia-Smirnova E.R. Antropologia professiǔ. Saratov, 2005. 462 pp. [Anthropology of Professions].

Romanov P.V., Iarskaia-Smirnova E.R. Professii.doc. Sotsialnye transformatsii professionalisma. Saratov, 2007. 408 pp. [Professions.doc. Social Transformations of Professionalism].

Romanov P.V., Iarskaia-Smirnova E.R. Antropologia professiǔ, ili postoronnim vkhod razreshen. Saratov, 2011.353 pp. [Anthropology of Professions, or Not only for personnel].

Romanov P.V., Iarskaia-Smirnova E.R. Antropologia professiř: granitsy zaniatosti $\mathrm{v}$ epokhu nestabilnosti. Moscow: Variant, 2012. 236 pp. [Anthropology of Professions: occupational boundaries in turbulent times].

Roy $O$. Afghanistan: Modelés Anthropologiques et Pacification // Cahiers du Monde russe et soviétique. 1990. Vol.31. P. 405-412.

Sadomskaya N. Soviet Anthropology and Contemporary Rituals // Cahiers du Monde russe et soviétique. 1990. Vol.31. P. 245-254.

Shimkin D. Siberian Ethnography: A Current Assessment // Cahiers du Monde russe et soviétique. 1990. Vol. 31, avril-septembre. P. 317-326.

Shnirelman V.A. The Emergence of a Food-Producing Economy in the Steppe and ForestSteppe Zone of Eastern Europe // The Journal of Indo-European Studies. 1992. Vol. 20. no. 1-2. P. 123-143.

Skalnik P. Community: struggle for a key concept in Soviet ethnography // Dialectical anthropology. 1981. Vol.6, No. 2. P. 183-191.

Skalnik P. Towards an understanding of Soviet etnos theory // South African Journal of Ethnology. 1986. No. 9. P. 157-166.

Skalnik P. Union Soviétique - Afrique du sud: les 'Théories' de l'etnos // Cahiers d'Etude africaines. 1988. Vol. 28, No. 2. P. 157-176.

Skalnik P. Soviet Ethnographïa and the National(ities) Question // Cahiers du Monde russe et soviétique. 1990. Vol. 31. P. 183-192;

Slezkine Yu. The Fall of Soviet Ethnography, 1928-38 // Current Anthropology Vol. 32, No. 4. 1991. P. 476-484.

Slezkine Yu. The USSR as a Communal Apartment, or How a Socialist State Promoted Ethnic Particularism // Slavic Review. Vol. 53, No. 2. P. 414-452.

Sokolovskiy S.V. Zerkala i otrazhenia ili esche raz o situatsii o rossïskoi antropologii // Antropologicheskii Forum. 2014. Vol. 20. P. 143-188 [Mirrors and Reflections or Once More on the Situation in Russian Anthropology].

Sokolovskiy S.V. (ed.) Innovatsii v antropologii. Vol. 1. Moscow, 20015. 151 pp.; Vol. 2. Tomsk, 2016. 304 pp. 
Sorin-Chaikov N. The Social Life of the State in Subarctic Siberia. Stanford Univ. press, 2003. $261 \mathrm{pp}$.

Steward J. Theory of cultures change: The methodology of multilinear evolution. Urbana, 1955

Tishkov V. The Crisis in Soviet Ethnography // Current Anthropology. 1992. Vol. 33, No. 4. P. 371-382.

Tishkov V. Post-Soviet Ethnography. Not a Crisis by Something More Serious // Anthropology \& Archeology of Eurasia. 1994. Vol. 33, No. 3. P. 87-92 (http://dx.doi.org/10.2753/AAE1061-1959330387).

Tisbkov V. Ethnicity, Nationalism, and Conflict in and after the Soviet Union: The Mind Aflame. London: Sage, 1996.

Tisbkov V. Zabyt' o natsii // Etnograficheskoe obozrenie. 1998. No. 5. P. 3-26 [Forget the Nation].

Tisbkov V., Shnirelman V. (eds.) Natsionalism v mirovoi istorii. Moscow: Nauka, 2007. 601 pp. [Nationalism in World History].

Tisbkov V., Filippova E. (eds.) Kul'turnaia slozhnost' sovremennykh natsii. Moscow: ROSSPEN, 2016. 384 pp. [Cultural Diversity of Contemporary Nations].

Tolstov S.P. Ocherki pervonachalnogo islama // Sovetskaia Etnografia. 1932. No. 2. P. 24-82 [Essays on Early Islam].

Vainstein O.B. Aromaty i zapakhi v kul'ture. Moscow: NLO, 2003. Vol.1. 603 pp.; Vol. 2. 663 pp. [Aromas and Smells in Culture].

Vermeulen H.F. Before Boas. The Genesis of Ethnography and Ethnology in the German Enlightenment. Lincoln: University of Nebraska Press, 2015. 746 pp.

Vitebsky P. Centralized Decentralization: The Ethnography of Remote Reindeer Herders under Perestroika // Cahiers du Monde russe et soviétique. 1990. Vol. 31, No. 2-3. P. 345-356. 


\section{ATTACHMENT}

Table 1. Urban anthropology publications in the journal Sovetskaia etnografia/Etnograficheskoe obozrenie, 1946-2016

\begin{tabular}{|l|l|l|l|l|l|l|l|l|}
\hline Popics & $1946-59$ & $1960-69$ & $1970-79$ & $1980-89$ & $1990-99$ & $2000-09$ & $2010-16$ & $\Sigma$ \\
\hline $\begin{array}{l}\text { Culture, household, daily life } \\
\text { and folklore of workers }\end{array}$ & 15 & 19 & 11 & 2 & 1 & 0 & 0 \\
\hline $\begin{array}{l}\text { City life ethnography and } \\
\text { research methods }\end{array}$ & 0 & 8 & 8 & 10 & 2 & 6 & 9 \\
\hline $\begin{array}{l}\text { Orientalist, Africanist and } \\
\text { Americanist urban studies }\end{array}$ & 4 & 3 & 9 & 0 & 1 & 0 & 1 & 43 \\
\hline $\begin{array}{l}\text { Ethnic demography, ethno- } \\
\text { sociology, ethnic ecology, and } \\
\text { ethno-psychology of urban } \\
\text { population }\end{array}$ & 0 & 6 & 8 & 11 & 2 & 3 & 10 & 40 \\
\hline $\begin{array}{l}\text { City history and urban } \\
\text { Architecture and } \\
\text { dwelling ethnography }\end{array}$ & 0 & 1 & 1 & 0 & 0 & 0 & 0 \\
\hline $\begin{array}{l}\text { Bio-anthropology } \\
\text { population genetics of urban } \\
\text { populations }\end{array}$ & & 0 & 0 & 1 & 1 & 0 & 0 & 2 \\
\hline Subculture studies Total & $\mathbf{2 1}$ & $\mathbf{3 8}$ & $\mathbf{3 8}$ & $\mathbf{2 7}$ & $\mathbf{8}$ & $\mathbf{2 8}$ & $\mathbf{2 9}$ & $\mathbf{1 8 9}$ \\
\hline
\end{tabular}

Table 2. Co-citation in Russian anthropologic journals (2012)

\begin{tabular}{|l|c|c|c|c|c|c|c|c|c|c|c|c|c|c|c|c|c|c|c|c|c|}
\hline & 1 & 2 & 3 & 4 & 5 & 6 & 7 & 8 & 9 & 10 & 11 & 12 & 13 & 14 & 15 & 16 & 17 & 18 & 19 & 20 & $\Sigma$ \\
\hline 1 & 367 & 21 & 0 & 0 & 12 & 11 & 14 & 12 & 8 & 17 & 0 & 0 & 13 & 5 & 0 & 0 & 0 & 5 & 38 & 13 & 536 \\
\hline 2 & 0 & 20 & 0 & 0 & 0 & 0 & 0 & 0 & 6 & 0 & 0 & 0 & 0 & 0 & 0 & 0 & 0 & 0 & 0 & 0 & 208 \\
\hline 3 & 58 & 0 & 203 & 0 & 29 & 21 & 0 & 0 & 1 & 0 & 0 & 0 & 0 & 0 & 0 & 17 & 0 & 0 & 12 & 0 & 341 \\
\hline 4 & 48 & 0 & 0 & 12 & 0 & 0 & 0 & 0 & 0 & 0 & 0 & 0 & 0 & 0 & 0 & 0 & 0 & 0 & 0 & 0 & 60 \\
\hline 5 & 45 & 0 & 131 & 0 & 140 & 11 & 0 & 0 & 0 & 0 & 0 & 0 & 0 & 0 & 0 & 0 & 0 & 0 & 0 & 0 & 327 \\
\hline 6 & 0 & 0 & 0 & 0 & 0 & 0 & 0 & 0 & 0 & 0 & 0 & 0 & 0 & 0 & 0 & 0 & 0 & 0 & 0 & 0 & 0 \\
\hline 7 & 14 & 0 & 0 & 0 & 0 & 0 & 164 & 10 & 0 & 0 & 0 & 0 & 11 & 0 & 0 & 0 & 0 & 0 & 0 & 0 & 199 \\
\hline 8 & 0 & 29 & 0 & 0 & 0 & 0 & 0 & 65 & 0 & 0 & 0 & 0 & 11 & 0 & 0 & 0 & 0 & 0 & 0 & 0 & 105 \\
\hline 9 & 0 & 0 & 0 & 0 & 0 & 0 & 0 & 0 & 0 & 0 & 0 & 0 & 0 & 2 & 0 & 0 & 0 & 0 & 0 & 0 & 2 \\
\hline 10 & 0 & 0 & 0 & 0 & 0 & 0 & 0 & 4 & 0 & 106 & 0 & 46 & 12 & 2 & 0 & 0 & 0 & 0 & 0 & 7 & 177 \\
\hline 11 & 0 & 0 & 0 & 0 & 0 & 0 & 0 & 0 & 0 & 0 & 196 & 0 & 0 & 0 & 0 & 0 & 0 & 0 & 0 & 0 & 196 \\
\hline 12 & 0 & 0 & 0 & 0 & 0 & 0 & 0 & 0 & 0 & 0 & 0 & 77 & 0 & 0 & 0 & 0 & 0 & 0 & 0 & 0 & 77 \\
\hline 13 & 0 & 0 & 0 & 0 & 0 & 0 & 0 & 0 & 0 & 0 & 0 & 0 & 0 & 0 & 0 & 0 & 0 & 0 & 0 & 0 & 0 \\
\hline 14 & 0 & 0 & 0 & 0 & 0 & 0 & 0 & 0 & 0 & 0 & 0 & 0 & 0 & 0 & 0 & 0 & 0 & 0 & 0 & 0 & 0 \\
\hline 15 & 0 & 0 & 0 & 0 & 0 & 0 & 0 & 0 & 0 & 0 & 0 & 0 & 0 & 0 & 200 & 0 & 0 & 0 & 0 & 0 & 200 \\
\hline 16 & 0 & 0 & 0 & 0 & 0 & 0 & 0 & 0 & 0 & 0 & 0 & 0 & 0 & 0 & 0 & 108 & 0 & 0 & 11 & 0 & 119 \\
\hline 17 & 0 & 0 & 0 & 0 & 0 & 0 & 0 & 0 & 0 & 0 & 0 & 0 & 0 & 0 & 0 & 0 & 96 & 0 & 18 & 0 & 114 \\
\hline 18 & 69 & 0 & 0 & 0 & 0 & 0 & 0 & 0 & 0 & 0 & 0 & 0 & 0 & 0 & 0 & 0 & 0 & 77 & 97 & 8 & 251 \\
\hline 19 & 0 & 0 & 0 & 0 & 0 & 0 & 0 & 0 & 0 & 0 & 0 & 0 & 0 & 0 & 0 & 0 & 0 & 17 & 141 & 8 & 166 \\
\hline 20 & 53 & 0 & 0 & 0 & 0 & 0 & 10 & 4 & 0 & 0 & 0 & 0 & 5 & 0 & 0 & 0 & 0 & 0 & 30 & 43 & 145 \\
\hline & 654 & 252 & 334 & 12 & 181 & 43 & 188 & 95 & 15 & 123 & 196 & 123 & 52 & 9 & 200 & 125 & 96 & 99 & 347 & 79 & \\
\hline
\end{tabular}

* figures in table lines reflect the number of citations of papers, published in anthropological journals, indicated in the head of the table; figures in columns reflect the numbers of citations of this journal materials in other journals, indicated in the first column of the table. 
1. Etnograpficheskoe obozrenie [Ethnographic Review]; 2. Vostok [Orient]; 3. Arkheologia, etnografia i antropologia Evrazii [Archaeology, Ethnology \& Anthropology* of Eurasia]; 4. Vestnik Instituta istorii, arkheologii i etnografii (Makhachkala) [Herald of the Institute of History, Archaeology, and Ethnography (Daghestan)]; 5. Vestnik antropologii, arkheologii i etnografii (Tyumen') [Herald of Anthropology*, Archaeology, and Ethnography (Tyumen)]; 6. Voprosy antropologii [Issues of anthropology*]; 7. Ab Imperio (Kazan']; 8. Vestnik Evrazii [Herald of Eurasia]; 9. Vostochnaia kollektsia [Oriental Collection]; 10. Zhurnal sotsiologii i sotsialnoi antropologii [Journal of sociology and social anthropology]; 11. Lichnost'. Kul'tura. Obschestvo [Person. Culture. Society]; 12. Mir Rossii. Sotsiologia. Etnologia [Universe of Russia. Sociology. Ethnology]; 13. Diaspory [Diasporas]; 14. Etnopanorama [Ethno-Panorama]; 15. Chelovek [Man]; 16. Gumanitarnye nauki v Sibiri [Humanities in Siberia]; 17. Slavianovedenie [Slavic Studies]; 18. Trditsionnaia kul'ture [Traditional Culture]; 19. Zhivaia starina [Antiquity Alive]; Antropologicheskii forum [Forum For Anthropology].

Note: 'anthropology*' means 'physical anthropology'. The red lines in the upper-left and lower-right corners of the Table show the groups of journals with maximum of co-citations; the groupings reflect the divide between 'political' anthropologists and 'folklorists'.

\section{Noted}

${ }^{1}$ As I argued elsewhere (Sokolovskiy 2014: 179) both domains and their research agendas have been for a long time linked with imperial and nationalist ideologies: the more anti-communitarian nationalities policy research with its various historical projects of nation-building (the predecessor to the current Russian nation was Soviet people project); and folkloristic ethnology with its roots in romantic nationalism of the XIX c. and the ideology of naroznik or populist movement, that continues to sponsor various local nationalisms, including Russian in its ethnic dimension.

${ }^{2}$ The Institute changed its name in 1991; prior to 1992 it consisted of two large branches in Moscow and St. Petersburg; in 1992 Kunstkamera (st. Petersburg's branch of the institute) became an independent institutions of the Russian Academy of Sciences.

3 Sergey Tolstov (1907-1976) became the director of IE AN in 1942 and organized archaeological research of the ancient Khorezm oasis; he established the department of ethno-archaeology at the IE AN. Besides, as a member of the Party, he initiated the turn to contemporaneity in ethnographic research (ethnography was viewed at the time as a predominantly historical discipline.

Julian Bromley (1921-1990) replaced Tolstov in 1966 and soon afterwards consolidated the views of his predecessors (particularly of Sergey Shirokogoroff and Nikolai Mogilianskiy) and colleagues (in particular Pavel Kushner, Sergey Tokarev, Nikolay Cheboksarov, and Viktor Kozlov) into what would be later known as the Soviet theory of ethnos.

Valery Tishkov (1941) was elected as the director of IA AN in 1989 and put much energy into polemics with the ethnos theory, advocating instead less primordialist concepts of ethnicity and ethnic identification; his other main contributions to broadening of the subject of anthropology were ethnic conflicts studies and applied research of 'inter-ethnic' relations in close co-operation with various state institutions (in 1992 he held the office of the Minister for Nationality Affairs).

After 1990s with the appearance of numerous new anthropological research centers, departments, chairs, and journals (not all of them surviving for long) the centralized character of the discipline gave way to more pluralist, uneven and less predictable developments in terms of research agenda and sub-discipline specialization.

${ }^{4}$ I am working for more than thirty years as research anthropologist at IEA RAS (I started my anthropological career at this institution back in in 1983 as a post-graduate, but spent several years before in field population genetics and bio-anthropological research in Western Siberia). Another source of my familiarity with the current situation in Russian anthropology is my current position as the editor-in-chief of the oldest Russian anthropological journal Etnograficheskoe obozrenie (Ethnographic Review, est. 1889) that I have held for the two consecutive terms (with one year off in-between), starting in 2004, and having served before that as an editorial board member. Still another evident source is my involvement in many associations and events taking place in Russian anthropology, including its bi-annual congresses, as well as my own academic research and lecturing. Communication with colleagues across the country from Vladivostok to Moscow and from Saint-Petersburg to Krasnodar is yet another invaluable source for the feel of the discipline's pulse.

${ }^{5}$ There are several hundred anthropologists, out of approximately one thousand-strong Russian anthropological community, who regularly publish on topics related to this field.

${ }^{6}$ The Eurasia Foundation ended its research programs support in Russia in 2004; Heritage Foundation left Russia in April 2010; USAID at the end of 2012; Open Society Foundation (part of the Soros foundation network) left the country in 2013; in January 2014 Kennan Institute for Advanced Russian Studies followed 
suit; in July 2015 they have been followed by the Moscow office of J. and K. MacArthur Foundation. There is a couple of research granting agencies with western funding that continue to operate in Russia (among them New Eurasia Foundation and Moscow Carnegie Centre), but they are engage either as a social development or political cancelling agencies and do not play any active role in academic research neither in social sciences, nor in humanities.

${ }^{7}$ I have to use quotation marks for 'ethnic' as most conflicts thus described were not ethnic by origin, by motives or even by ethnicity of the warring opponents, but were perceived and portrayed as such due to prevailing primordialist ideology both among scholars and ruling elites.

${ }^{8}$ The joint research venture was initiated by the American side, represented by Research Institute for the Study of Man (RISM) and its director Dr. Vera D. Rubin (1911-1985), who studied anthropology at Columbia University under Ruth Benedict, Margaret Mead and Julian Steward. An active team member was another student of Ruth Benedict, and also a RISM senior fellow Sula Benet (1903-1982). Both women were of Eastern European Jewish origin, born in Moscow and Warsaw, respectively; both studied cannabis and its effects on human health.

${ }^{9}$ In early 1980s a number of books by leading ecologists were translated in Russian and published by "Progress" publishing house; among them "Précis d'Ecologie" by Roger Dajoz (translation publ. in 1975); "Energy Basis for man and Nature" by Howard and Elisabeth Odum (translation publ. in 1978); "Communities and Ecosystems" by Robert Whitaker (translation publ. in 1980); "Evolutionary Ecology" by Eric Pianka (translation publ. in 1981), "Introduction to Population Biology and Evolution" by Otto and Dorothy Solbrig (translation publ. in 1982)

${ }^{10}$ The journal was established in 1889 under the same name, but later had been twice renamed (Etnografia in 1926, and Soviet etnografia in 1930). Its initial name was restored in 1992. It is the oldest and most influential anthropological academic publication in the country, with few rivals in terms of the number of research areas covered and the geography of its contributors.

${ }^{11}$ According to the All-Russian population census of 2010 among 137227107 persons, who provided the answer on the question on ethnic group affiliation, 136019 395, or 99.11\% informed that they know Russian (http://www.gks.ru/free_doc/new_site/perepis2010/croc/Documents/Vol4/pub-04-03.pdf).

${ }^{12}$ For details see the website of the Centre for Visual Anthropology at Moscow State University (http://visant.etnos.ru/fest/rfaf_1.php\#up).

${ }^{13}$ Among them quarterly scientific journal of the Russian Academy of Sciences "Voprosy estestvoznania i tekhniki” (http://vietmag.org/?lang=en) 